\title{
Some observations and remembrances of Kenneth W. Spence
}

\author{
Allan R. Wagner \\ Yale University, New Haven, Connecticut
}

\begin{abstract}
Kenneth W. Spence was among the most influential learning theorists of the 20th century. He was not only a pioneer in the genesis of computational models but an articulate systematist and scholar regarding the place of theory in psychology. The following observations and remembrances were offered at the University of Iowa as part of a tribute to his contributions on the 100th anniversary of his birth.
\end{abstract}

I was fortunate to study under Kenneth Spence, as a graduate student at the University of Iowa, from 1956 to 1959. At that time, Spence was enjoying the height of his reputation. He had been elected to membership in the Society of Experimental Psychologists and awarded its Warren Medal for his theoretical efforts. He had received the Distinguished Scientific Contribution Award of the American Psychological Association in the first year in which it was given. He had just delivered the prestigious Silliman Lectures at Yale, which were published in the volume Behavior Theory and Conditioning (Spence, 1956). And, he had recently been elected to the National Academy of Sciences.

Spence was a leading learning theorist, when "learning theory" dominated academic psychology. It is a comment upon the area, as well as upon Spence's position in it, that in the 6-year period from 1962 through 1967 (the year in which he died) Spence was the most cited psychologist in a survey of the 14 journals judged to be the most prestigious in the field (Myers, 1970).

Since that time much has changed in academic psychology. Learning has had to share the stage, as best it can, with developmental processes and evolutionary principles, and our mechanistic theories about learned or unlearned behavioral phenomena have turned more to neurobiology. Many who today share Spence's interests call themselves behavioral neuroscientists, or computational neuroscientists, or even cognitive neuroscientists, rather than learning theorists. Indeed, enough has changed that many may be unclear about what the "learning theory" is, or was, to which Spence contributed, or what significant role he played.

I will offer a few observations about Kenneth Spence, about why he had the reputation he did, and about what enduring legacy he left. Several biographical memoirs and systematic commentaries have been written by other Spence students, Abram Amsel (1995), Howard Kendler (1967), and Janet Taylor Spence (Kendler \& Spence, 1971), as well as by one of his own teachers, Ernest Hilgard (1967). All mention his extraordinary contributions as a theorist, as an experimentalist, as a methodologist, as a scholar and as a teacher. I will comment on several of these, and make more of a theme out of his pragmatism, as I saw it.

\section{Theorist}

Spence's reputation as a theorist was surely set by his papers on discrimination learning published in the mid 1930s (Spence, 1936, 1937) when he was just a few years beyond the $\mathrm{PhD}$. The theory was unprecedented. It was among the first to make genuine mathematical deductions from theory, and can be judged to be the first in which the predictions were not transparent in its individual assumptions. Several participants in the present tribute (Lazareva, Miner, \& Wasserman, 2008; Pearce, Esber, \& George, 2008; Urcuioli, 2008; Wagner, 2008) comment in some detail upon Spence's theory of discrimination learning, because much of it persists in current theories. Here, I will only take the opportunity to be concrete, by briefly characterizing certain of the original notions.

Lashley (1929) had described a salient pattern of data in the learning of a two-choice discrimination by rats, as, for example, in a jumping stand. When presented with a triangle versus a circle, counterbalanced in presentations to the right and left, animals might be rewarded for approaching the triangle and not rewarded for approaching the circle. The pattern that Lashley reported was that animals often showed an extended period of chance performance, followed by a relatively abrupt change to a high percentage of correct responding. Of this pattern, Lashley, and Krechevsky (1932) after him, suggested that the essential learning concerning the relevant discriminanda resulted from the animal's testing and confirming the correct hypothesis during the rapidly changing portion of the function, with the practice preceding and the errors following being irrelevant to the final solution.

Spence (1936) proposed, instead, that learning to the relevant stimuli was continually accruing over training, even though the gradual changes involved might not be apparent in the choice measure. The central assumption was that each choice of a reinforced display produced an increment in the excitatory tendency of each of the components

A. R.Wagner, allan.wagner@yale.edu 
of the display, whereas each choice of a nonreinforced display produced an increment in an inhibitory tendency toward each component of that display. With the reinforcement contingencies described in the example problem, one would expect that over the course of the training sequence any differential tendencies controlled by the spatial stimuli would be equalized, and that the tendency controlled by the triangle would be caused to grow larger than that of the tendency controlled by the circle. The important derivation was that the gradual differential growth of the latter tendencies could well be masked in the choice measure by any substantial differences in the spatial (or other) tendencies. Spence presented tabled values showing how what would appear to be an abrupt delayed learning effect might instead be a result of the cumulating differences in the tendencies to the triangle versus circle only being able to be seen after some training, over the initial control exerted by the differential tendencies of the spatial cues.

Spence proposed one way to test the alternative theories, by the reversal of the significance of the discriminanda during the presolution period, when the animals were still responding at a chance level. This and other tests formed a long and productive history known as the "continuity versus noncontinuity controversy." I think that most reviewers (e.g., Goodrich, Ross, \& Wagner, 1961) awarded the original battle to Spence, but its importance was less in who won than in how it changed the level of our theoretical interpretations.

Spence's second theoretical gambit is the subject of a companion paper by Wasserman (Lazareva et al., 2008). I can, thus, be very brief. It was in response to an observation by Köhler (1918), who had reported that chimpanzees and chicks, after being trained, in a two-choice visual discrimination problem to choose one sized stimulus, rather than another, would show transposition of what was learned in a novel test with the reinforced training stimulus and one more distant from the nonreinforced stimuluschoosing the latter over the former. Köhler's interpretation was that the animals had apparently learned to respond to the relationship "larger" of the two training stimuli, so as to respond on the same basis to the larger of the two test stimuli. Spence (1937) proposed an alternative based on assumed generalization gradients around the training stimuli. He supposed that the excitatory and inhibitory tenden- cies assumed in his prior theorizing would have maxima at the reinforced and nonreinforced stimuli, respectively, but would each show generalization to other similar stimuli, in the manner depicted in Figure 1. On the assumption, previously made, that the approach tendency to any stimulus is the result of its excitatory tendency minus its inhibitory tendency, one can anticipate that the reinforced stimulus in training would not necessarily be the most responded to. Indeed, one can anticipate transposition in some comparisons, with some larger stimuli having a stronger tendency.

Like the continuity-noncontinuity controversy, this theory about the causes of transposition had a very constructive product (Riley, 1968). It anticipated the so-called breakdown of transposition with very extreme stimuli, and a failure of transposition following an intermediate size problem. It is also congruent with the more modern findings of a peak shift in generalization testing following simple go/no-go instrumental training (Hanson, 1959). A voluminous literature eventually accrued, especially contrasting and characterizing the differences in transposition among children of different ages and of different linguistic abilities (Kendler \& Kendler, 1962). The important product, as I see it, was less in whether Köhler or Spence was correct, than in how much more sophisticated our theories were encouraged to be in order to deal with the issues involved.

Over the next 30 years Spence elaborated on his theory of discrimination learning (e.g., Spence, 1940, 1952b, 1960), but turned more and more to the attempt to characterize the strengthening and weakening of the elementary excitatory and inhibitory tendencies assumed to be involved, via the study of simple instrumental and Pavlovian learning. A major contribution was to the understanding of incentive motivation. He, along with others, such as Neal Miller (1959) and O. Hobart Mowrer (1960), followed Clark Hull $(1931,1952)$ in assuming that instrumental behaviors are importantly mediated and motivated by fractional anticipatory responses - things like $r_{\mathrm{g}}-\mathrm{s}_{\mathrm{g}}$, fear, and anticipatory frustration - related to the ultimate reinforcers involved, and that the rules for the acquisition of such motivational processes could be investigated through the study of Pavlovian conditioning. Spence's 1956 book Behavior Theory and Conditioning remains an important source for the basic literature concerned with factors that

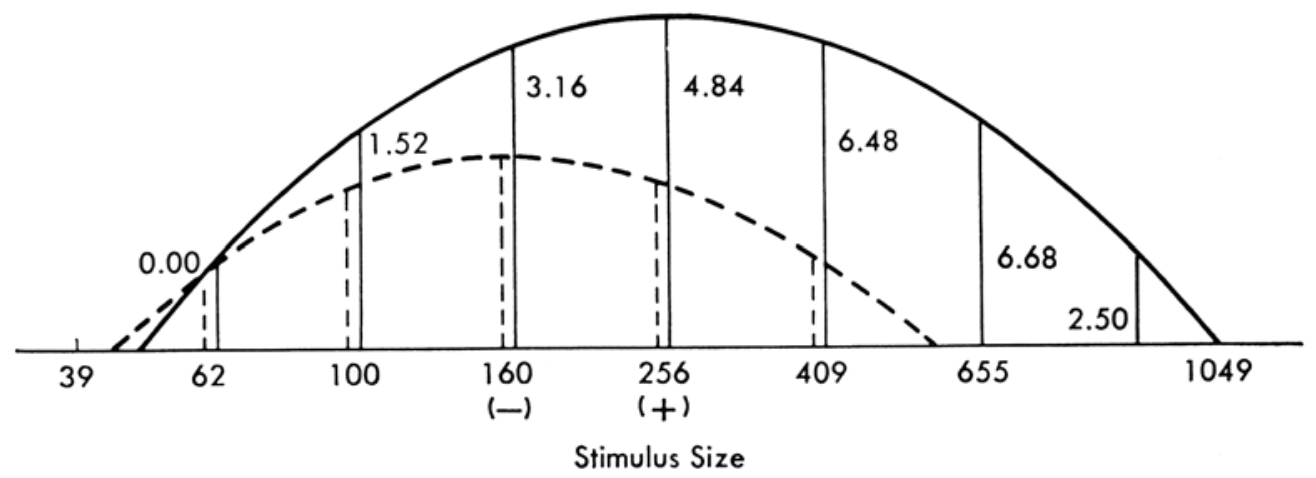

Figure 1. Diagrammatic representation of the excitatory (solid) and inhibitory (dashed) generalization functions proposed by Spence to result from the training with stimulus 256 reinforced $(+)$ and stimulus 160 nonreinforced (-). Redrawn from Spence (1937). 
determine appetitive incentive motivational processes, and how such processes influence instrumental performance.

In the last period of his life, Spence focused largely on the study of human eyeblink conditioning (Spence, 1953, 1966; Spence \& Ross, 1959) with the goal of understanding better the associative learning involved, and how its expression was influenced by motivational (Runquist \& Spence, 1959; Spence \& Runquist, 1958; Spence \& Taylor, 1951) and cognitive (Spence, 1963, 1966; Spence \& Goldstein, 1961) processes. That human eyeblink performance was, indeed, revealed in this research to be so highly dependent upon complex cognitive processes led Kenneth Goodrich, Leonard Ross, and me, working together as graduate students in Spence's laboratory, to undertake the first study of eyeblink conditioning in the rabbit. That preparation, owing to the efforts of many investigators, is by now one of the best understood instances of Pavlovian conditioning, at both the behavioral and neurobiological level.

\section{Methodologist}

Spence left his mark on learning theory not only by example, but also by articulating better than others in his time the potential value of theory, in general, and the criteria for its evaluation. A series of articles in Psychological Review carried such titles as "Operationism and Theory in Psychology" (Bergmann \& Spence, 1941), "The Nature of Theory Construction in Contemporary Psychology" (Spence, 1944), "The Postulates and Methods of 'Behaviorism"" (Spence, 1948), and "Mathematical Formulations of Learning Phenomena" (Spence, 1952a).

In his methodological stance, Spence was above all a pragmatist. In order to better understand the learning process, he advocated the concentrated study of Pavlovian and Thorndikian conditioning. There were strong antecedents to this position, in the emphasis received from the British Associationists, concerning the fundamental nature of the association of sense data and the principles of adaptive hedonism. It was apparent that these could be objectively investigated via the techniques presented by Pavlov (1927) and Thorndike (1911), respectively. But, what Spence emphasized (e.g., 1956) was that Pavlovian and Thorndikian conditioning are among the simplest of learning phenomena, and more likely to submit to scientific understanding than more complex instances. This is a pragmatic place to start to build a theory.

Spence theorized about how in these simple learning situations experimental stimuli come to control learned responses. In the course of this, he emphasized that the nature of the functional stimuli needs to be empirically determined in different situations (as in the previously mentioned instance of transposition) and could be expected to be influenced not only by the environmental stimuli presented but by such things as the animals' receptor-orienting behaviors and the specific contingencies of training (Spence, 1940, 1945). Likewise, he emphasized that the nature of the learned response needs to be empirically determined in each training situation, and more often than not appears to be better characterized as a molar act (such as "approaching a discriminandum" in selective learning) than as more molecular actions (Spence, 1952b). In this emphasis, Spence agreed with Skinner (1938), that the finding of lawful stimulus-response relationships depends upon the useful characterization of the stimulus and response classes involved. It is another reflection of his pragmatism.

Spence took issue with Skinner (1950), of course, in the advocacy of abstract, theoretical constructs. Spence (see 1944) took the position that such constructs are not restricted in their usefulness to mature theories, where abstract principles are formulated to allow the integration of functional relationships that otherwise might appear unrelated. Rather, he proposed that, even in less developed areas of knowledge, abstract constructs that are proposed to intervene between antecedents and presumed consequences can aid in the very discovery of lower-order laws about behavior. His aforementioned proposals concerning "excitatory" and "inhibitory" tendencies, with their assumed "generalization gradients" in discrimination learning exemplified such employment of theoretical constructs, and were defended as either being useful or not. We take for granted, today, much about behavior theory that Spence was forceful in clarifying in his time (see also Hull, 1943; Miller, 1959; and Tolman, 1932).

Spence is often referred to (Amsel 1995; Kendler \& Spence, 1971) along with Hull, Miller, Mowrer, and others of the Yale school, as a "neobehaviorist." But, what kind of behaviorism is neobehaviorism? Ignoring other systematic commitments that are orthogonal to behaviorism (e.g., whether one is an environmentalist vs. a nativist, or is more or less accepting of abstract theory), I would argue that there are three essential forms of behaviorism, each having to do with the place of mental discourse. Watson (1913) proposed that the basic subject matter of psychology was not mental content, as revealed through introspection, but rather the behavior of organisms, as verifiable through objective observation. This rejection of mental content is what is recognized as methodological behaviorism. If one is a theorist and introduces abstract concepts in the service of explanation, there are many choices about what kind of concepts might be potentially useful. The rejection of mentalistic concepts in one's theory of behavior can be termed theoretical behaviorism. Beyond this, one might reject mentalistic discourse for any purpose, such as addressing issues in epistemology. This wholesale rejection of mentalistic discourse is metaphysical behaviorism. As Gustav Bergmann (1956) said, all psychologists, whether they know it or not, are methodological behaviorists. Metaphysical behaviorism has been rejected by most philosophers as well as by the man on the street, but is irrelevant to our concern. What is significant is that Spence was a theoretical behaviorist, relatively unfriendly to the use of concepts drawn from mentalistic discourse in our theories of learning.

Spence took this position as a cautious step that guarded against the carryover of unintended and unexamined suppositions from folk psychology into one's theoretical interpretation. Thus, Spence (1936) criticized Krechevsky's (1932) aforementioned interpretation of the apparent sudden solution of discrimination problems in terms of the animal's trying out of various "hypotheses," because readers, and Krechevsky himself, appeared to go beyond theoretical definition of the concept and imbue it with all of the attributes associated with it in our general language. But, Spence was, in the final analysis, open to all theory that might be 
of demonstrated usefulness. In fact, of the alternative theorists of his day, Spence (1951) was most respectful of Tolman (1932) and his "purposive" theorizing that was built around mentalistic, "expectancy" concepts. Spence (1944) criticized Tolman's formulations only as being "programmatic," and not precisely enough articulated to be critically testable.

Abram Amsel, another Spence student whose theorizing on frustrative nonreward (Amsel, 1958) I supported and extended in my early studies (e.g., Wagner, 1963, 1969), was critical of some of my later theorizing, calling me a "lapsed neobehaviorist" (Amsel, 1989). The central idea in the theory (Wagner, 1976, 1978) that Amsel criticized is that a stimulus that is pre-represented in active memory does not provoke the same processing that it otherwise would. There is use of mentalistic terminology in this theory - for example, in the proposition that a prerepresented stimulus will not be "rehearsed" to the degree that it otherwise would be. But I think that the theory has been rather useful, allowing us to explain and integrate a wide variety of learning phenomena. This includes such things as the conditioned diminution of the unconditioned response in Pavlovian conditioning, the context-specificity of long-term habituation, and a considerable number of self-generated and associatively generated priming effects (Wagner, 1976, 1978, 1981).

This theory, as Amsel stated, is outside of the theoretical behaviorism that Spence favored. But it is not outside of the more general pragmatic stance that Spence took about theory. What he taught all of his students is that one can draw one's theoretical ideas from anywhere, from computer science, the lottery, mental discourse, conditioningextinction tenets-anywhere. The test is whether or not they are scientifically useful.

\section{Teacher}

Spence directed $75 \mathrm{PhD}$ theses. Few have come close to directing that many in such a short career. It was once said (if only by those late in the number who were looking for a position) that almost every major psychology department in the United States had a Spence PhD on its faculty. On this ground, as well as others, his progeny have had considerable impact.

One's thesis director may generally be remembered in toolarge terms. But one can believe that such terms are relatively appropriate in the case of Kenneth Spence. I remember him as a person of extraordinary presence, who appeared naturally to be at the center of things. He made a point of being the "Head" of the Psychology Department at the University of Iowa, not its Chairperson. He taught not only a twosemester lecture course on learning to all first-year graduate students, but a different graduate seminar each year after that to those who focused on learning. In these courses, he was painstaking in his scholarship and a model of organization, as befitting the fact that each seminar almost always ended in a new theoretical paper or set of ideas for student theses. At scheduled or impromptu social events (of which there were many) Spence would take a position in the room and wait for his audience to congregate. Then he would "hold court," continuing lectures that had begun elsewhere. There was little genuine dialogue in any of these interactions. The other faculty in the department were deferential, including those who were substantial intellects in their own right. It is little wonder that Spence's students were generally intimidated in his presence. He was always "Dr. Spence," never "Kenneth."

This does not mean that we students were unmotivated or unable to maintain some human perspective. At the end of my first year as a graduate student, I was led into directing a brief movie that was intended to be a (mostly) good-natured spoof. Spence and others of the Iowa faculty were duped into being filmed so that a "fitting" sound track could be dubbed in. We presented Spence as urging the audience to "get out of the rat lab and into the field," on the premise that "Once we understand the complex, the simple will be obvious." That still has the ring of authority that we otherwise heard in Spence's pronouncements.

In the classroom and elsewhere, Spence took us inside his world, and we soaked it up. He was a fount of information about the players in the field that we had only read about, about the history of departments and organizations that we came to know had a human scale, and about grander theoretical musings than we had ever thought about.

It took a while, as a student, to separate the confidence that Spence had about his methodological stance from the confidence that he had about his theories. The former was never seen to waver. But in every consideration of an unsolved theoretical issue, Spence would typically propose several different possibilities and entertain any that appeared amenable to test. He was always cognizant of the provisional nature of any of our theories, including his own.

As previously mentioned, Spence directed $75 \mathrm{PhDs}$. Clark Hull, at Yale, also had a great impact on our field. Indeed, his theoretical position and that of Spence were sufficiently joined that they were often referred to as the Hull-Spence theory (e.g., Logan, 1959). In comparison with Spence, however, Hull produced only a quarter the number of $\mathrm{PhDs}$, and not a one followed him as an important, continuing contributor to learning theory per se. (Spence, if one is wondering, studied with Hull, but did his $\mathrm{PhD}$ thesis under Robert Yerkes at Yale, not with Hull.)

What was different between the Spence training and the Hull training? Both Hull and Spence were passionate and articulate in their convictions. I think the difference was this: Hull, I am told, personally presented the task to the next generation of students as fleshing out the details of the schema he had envisioned. The important steps had been taken. Spence, I know, presented the task to the next generation as one of creating a better theory than existed. The firm foundation that he assumed and attempted to impart was the understanding of what abstract theory is and how it guides scientific pursuit, not in the current approximations. It was an empowering message. His students could think that their contributions might make some difference.

\section{AUTHOR NOTE}

Correspondence concerning this article should be addressed to A. R. Wagner, Yale University, P.O. Box 208205, New Haven, CT 06520 (e-mail: allan.wagner@yale.edu).

\section{REFERENCES}

AMSEL, A. (1958). The role of frustrative nonreward in noncontinuous reward situations. Psychological Bulletin, 55, 102-119. 
Amsel, A. (1989). Behaviorism, neobehaviorism, and cognitivism in learning theory: Historical and contemporary perspectives. Hillsdale, NJ: Erlbaum.

Amsel, A. (1995). Kenneth Wartinbee Spence. Biographical Memoirs, 66, 335-351.

Bergmann, G. (1956). The contribution of John B. Watson. Psychological Review, 63, 265-276.

Bergmann, G., \& Spence, K. W. (1941). Operationism and theory in psychology. Psychological Review, 48, 1-14.

GoOdRICH, K. P., Ross, L. E., \& WAGNER, A. R. (1961). An examination of selected aspects of the continuity and noncontinuity positions in discrimination learning. Psychological Record, 11, 105-116.

Hanson, H. M. (1959). Effects of discrimination training on stimulus generalization. Journal of Experimental Psychology, 58, 321-334.

HilgaRD, E. R. (1967). Kenneth Wartinbee Spence. American Journal of Psychology, 80, 314-318.

HuLL, C. L. (1931). Goal attraction and directing ideas conceived as habit phenomena. Psychological Review, 38, 487-506.

Hull, C. L. (1943). Principles of behavior. New York: AppletonCentury-Crofts.

Hull, C. L. (1952). A behavior system. New Haven, CT: Yale University Press.

Kendler, H. H. (1967). Kenneth Spence, 1907-1967. Psychological Review, 74, 335-341.

Kendler, H. H., \& KendLeR, T. S. (1962). Vertical and horizontal processes in problem solving. Psychological Review, 69, 1-16.

Kendler, H. H., \& Spence, J. T. (1971). Tenets of neobehaviorism. In H. H. Kendler \& J. T. Spence (Eds.), Essays in neurobehaviorism: A memorial volume to Kenneth Spence (pp. 11-40). New York: Appleton-Century-Crofts.

KöHLER, W. (1918). Nachweis einfacher Strukturfunktionen beim Schimpansen und beim Haushuhn: Über eine neue Methode zur Untersuchung des bunten Farbensystems. Abhandlungen der Königlich-Preussische Akademie der Wissenschaften: PhysikalischMathematische Klasse, No. 2, 1-101.

Krechevsky, I. (1932). "Hypotheses" versus "chance" in the presolution period in sensory discrimination-learning (University of California Publications in Psychology, Vol. 6, No. 3, pp. 27-44). Berkeley: University of California Press.

LASHLEY, K. S. (1929). Brain mechanisms and intelligence. Chicago: University of Chicago Press.

Lazareva, O. F., Miner, M., \& Wasserman, E. A. (2008). Multiplepair training enhances transposition in pigeons. Learning \& Behavior, 36, 174-187.

Logan, F. A. (1959). The Hull-Spence approach. In S. Koch (Ed.), Psychology: A study of a science. Vol. 2: General systematic formulations, learning, and special processes (pp. 293-358). New York: McGrawHill.

MiLleR, N. E. (1959). Liberalization of basic S-R concepts: Extensions to conflict behavior, motivation and social learning. In S. Koch (Ed.), Psychology: A study of a science. Vol. 2: General systematic formulations, learning, and special processes (pp. 196-292). New York: McGraw-Hill.

Mowrer, O. H. (1960). Learning theory and behavior. New York: Wiley. Myers, C. R. (1970). Journal citations and scientific eminence in contemporary psychology. American Psychologist, 25, 1041-1048.

Pavlov, I. (1927). Conditioned reflexes (G. V. Anrep, Ed. \& Trans.). London: Oxford University Press.

Pearce, J. M., Esber, G. P., \& George, D. N. (2008). The nature of discrimination learning in pigeons. Learning \& Behavior, 36, 188-199.

Riley, D. A. (1968). Discrimination learning. Boston: Allyn \& Bacon.

Runquist, W. N., \& SPENCE, K. W. (1959). Performance in eyelid conditioning related to changes in muscular tension and physiological measures of emotionality. Journal of Experimental Psychology, 58, 417-422.

SkINNER, B. F. (1938). The behavior of organisms. New York: AppletonCentury-Crofts

SKINNER, B. F. (1950). Are theories of learning necessary? Psychological Review, 57, 193-216.

SPENCE, K. W. (1936). The nature of discrimination learning in animals. Psychological Review, 43, 427-449.

SPENCE, K. W. (1937). The differential response in animals to stimuli varying within a single dimension. Psychological Review, 44, 430-444.
SPENCE, K. W. (1940). Continuous versus non-continuous interpretations of discrimination learning. Psychological Review, 47, 271-288.

SPENCE, K. W. (1944). The nature of theory construction in contemporary psychology. Psychological Review, 51, 47-68.

SPENCE, K. W. (1945). An experimental test of the continuity and noncontinuity theories of discrimination learning. Journal of Experimental Psychology, 35, 253-266.

SPENCE, K. W. (1948). The postulates and methods of "behaviorism." Psychological Review, 55, 67-78.

SPENCE, K. W. (1951). Theoretical interpretations of learning. In S. S. Stevens (Ed.), Handbook of experimental psychology (pp. 690-729). New York: Wiley.

SPENCE, K. W. (1952a). Mathematical formulations of learning phenomena. Psychological Review, 59, 152-160.

SPENCE, K. W. (1952b). The nature of the response in discrimination learning. Psychological Review, 59, 89-93.

SPENCE, K. W. (1953). Learning and performance in eyelid conditioning as a function of intensity of the UCS. Journal of Experimental Psychology, 45, 57-63.

SPENCE, K. W. (1956). Behavior theory and conditioning. New Haven, CT: Yale University Press.

SPENCE, K. W. (1960). Behavior theory and learning, selected papers. Englewood Cliffs, NJ: Prentice-Hall.

Spence, K. W. (1963). Cognitive factors in the extinction of the conditioned eyelid response in humans. Science, 140, 1224-1225.

SPENCE, K. W. (1966). Cognitive and drive factors in the extinction of the conditioned eye blink in human subjects. Psychological Review, 73, 445-458

Spence, K. W., \& Goldstein, H. (1961). Eyelid conditioning performance as a function of emotion-producing instructions. Journal of Experimental Psychology, 62, 291-294.

SPEnCE, K. W., \& Ross, L. E. (1959). A methodological study of the form and latency of eyelid responses in conditioning. Journal of Experimental Psychology, 58, 376-385.

Spence, K. W., \& Runquist, W. H. (1958). Temporal effects of conditioned fear on the eyelid reflex. Journal of Experimental Psychology, $\mathbf{5 5}, 613-616$.

Spence, K. W., \& TAYlor, J. [A.] (1951). Anxiety and strength of the UCS as determiners of the amount of eyelid conditioning. Journal of Experimental Psychology, 42, 183-188.

Thorndike, E. L. (1911). Animal intelligence. New York: Macmillan.

Tolman, E. C. (1932). Purposive behavior in animals and men. New York: Appleton-Century-Crofts.

UrCuioli, P. (2008). The nature of responding in ambiguous-cue discrimination learning: Simon effects, discrimination failure and value transfer. Learning \& Behavior, 36, 200-209.

WAGNER, A. R. (1963). Conditioned frustration as a learned drive. Journal of Experimental Psychology, 66, 142-148.

WAGNER, A. R. (1969). Frustrative nonreward: A variety of punishment? In B. A. Campbell \& R. M. Church (Eds.), Punishment and aversive behavior (pp. 157-181). New York: Appleton-Century-Crofts.

WAGNer, A. R. (1976). Priming in STM: An information processing mechanism for self-generated or retrieval-generated depression in performance. In T. J. Tighe \& R. N. Leaton (Eds.), Habituation: Perspectives from child development, animal behavior and neurophysiology (pp. 95-128). Hillsdale, NJ: Erlbaum.

WAGNER, A. R. (1978). Expectancies and the priming of STM. In S. H. Hulse, H. Fowler, \& W. K. Honig (Eds.), Cognitive processes in animal behavior (pp. 177-209). Hillsdale, NJ: Erlbaum.

WAGNER, A. R. (1981). SOP: A model of automatic memory processing in animal behavior. In N. E. Spear \& R. R. Miller (Eds.), Information processing in animals: Memory mechanisms (pp. 5-47). Hillsdale, NJ: Erlbaum.

WaGNeR, A. R. (2008). Evolution of an elemental theory of Pavlovian conditioning. Learning \& Behavior, 36, 253-265.

Watson, J. B. (1913). Psychology as the behaviorist views it. Psychological Review, 20, 158-177.

(Manuscript received April 28, 2008; accepted for publication April 29, 2008.) 